$620.179 .11: 620.191 .5: 669.14-122.2-415$

$' 74-\mathrm{S} 677$

(339) 冷延鋼板の表面污れ検出装固の開発

新日本製鐵湖君津製鐵所工博宮川一男 ○市嶋勇

渡辺誠一得道芳弘杉本隆夫

1. 緒 言

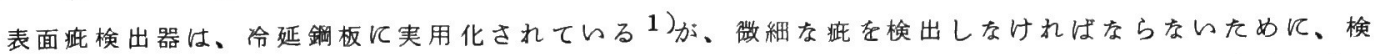
出感度を高使用している。この際、被検材表面に実用上何ら支障のない污れが存在した場合にも、 疵と同等の検出信号を発し、無用子損失をるたらしていた。そてて検出信号を战検出回路と並列に污れ 判別検出回路をる5け、污れと疵を識別検出しらる装置を開発したので報告する。

2. 作動原理と污れ検出回路の特色

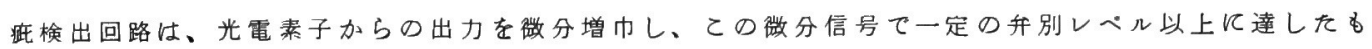
のを欠陷出力とするが、污れ検出信号は、光電素子加らの出力積分し、この積分出力が、一定の伯に 達しなかつたすのを欠陷信号とする。以下に本装置の特色を記す。

(1) 顛分方式である。

(2)回転鏡 16 面の反射率差がさり机いので16 走査積分方式とした。

(3) 光電素子出力信号のピーク值てAGC(Automatic GainC'ontrol) 泉とる方式とした。

(4) 板市変動に応し、走查視界に比例する基隼積分値て割り算を行 5 方式とした。

3. 試 験 結 果

3. 1. 実 験 室 テ スト

上述の作動老行な5装置を試作し、黒色マ スクで視界をさえざり、このマスク率と污れ 信号出力の関係図 1 亿示す。生冷延板の 污れを検査負が判定した評点と出力の関係を 図2 亿示した。結果はきわ信度の対応関 係を示している。

\section{2. オンラインテスト}

試作材てのオンラインテスト結果を図 3 に 示す。チャート紙上の数字は検定員が判定し た結果でり、よい対応を示している。さら に実材ての対応試験結果を表 1 亿示した。検 查員が重污九と判定した部分の一部に局部的 污れてあつたため、検出器は重污れと判定し なかつたるのがある。

4. 結言

光走查式の表面疪検出装㯰儿積分方式の污 れ検出回路を製作し、オンラインテストラン を行なつた結果、をわめて良好な結果を得た 引用文献

1 ) 宮川、市嶋：計測と制御 11,9 , 9 , 805, ('7 2)

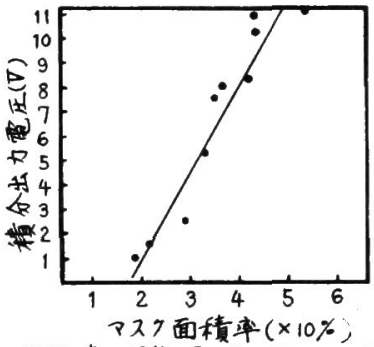

图1素子受光量と出力電压の周係

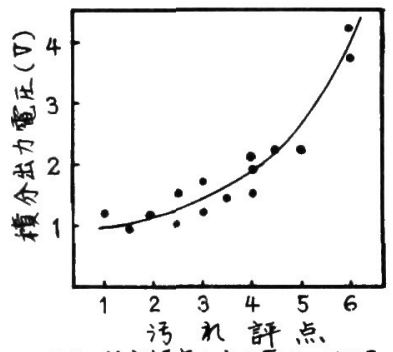

四2 梌定評点と出力電压の阅係

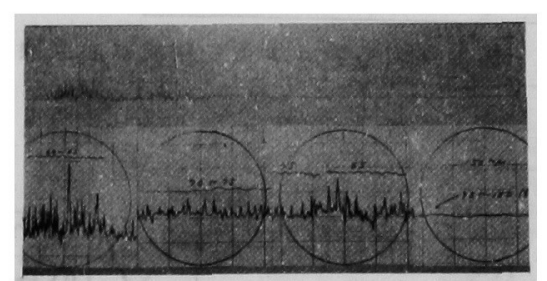

因3オンラインテスト記録結是

表1实穞動試䁩結果

\begin{tabular}{|c|c|c|c|}
\hline \multirow[b]{2}{*}{ 污れの程度 } & \multirow[b]{2}{*}{ 工仙数 } & \multicolumn{2}{|c|}{ 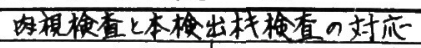 } \\
\hline & & 内視錸出佃数 & 本株の検出细数 \\
\hline 整度の污水 & 1 & 157 & 155 \\
\hline 中程度の污れ & 7 & 24 & 23 \\
\hline 重污 n & 5 & 166 & 131 \\
\hline
\end{tabular}


$74-\mathrm{S} 678$

669.14-122.2-415: 535.3: 620.179.11

\section{（340）粗面における光の反射分布の解析}

1. 概 要

新日本製鉄基碳研究所

設備技術センター
高藤 英生, ○石田次雄, 草鹿履一郎

渡辺哲夫, 瀬谷淳美

冷延鋼板などの表面からの反射光によって，その表面の粗さを評価でるはずであるてれを、レ一 ザー光と, 電算機をつないだ粗度計に上って定量的に裹付けた。

\section{2 実 験 四 1}

光学ゴニオメータ一を使用して，鐥板面からの二 次元的な反射分布 $I=I(\theta, \varphi)$ を测定し, 同一部 分を粗度解析システムて各種粗度の解析を行なった。

レーザー: $\mathrm{He}-\mathrm{Ne} \quad \lambda=0.6328 \%$

入射角: $\theta_{1}=45^{\circ}$

粗度解析 : $\mathrm{z}(\mathrm{x})$ の確率密度分布 $\mathrm{p}(\mathrm{z})$ と $\sigma$

$z(x)$ の自己相関 C $(\tau)$ と $\mathrm{T}$.

RMS, PPI etc

サンブル：ダル( $\begin{array}{ll}1 & 8\end{array}$ 枚 $) 、$ スクラッチダル( 2 枚 $)$

ブライト( 2 枚)

\section{3. 結 果}

1 ) 反射分布測定例

2) 反射分布のピーク值と半值巾の関係

3）反射分布の半値巾と $\sigma / \mathrm{T}$ の関係

理論的検討と実験から，ダ鋼板面の反射分布之 粗度の間には次の関係があるてとがわかった。

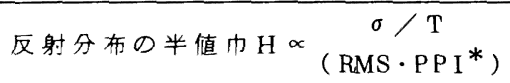

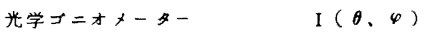
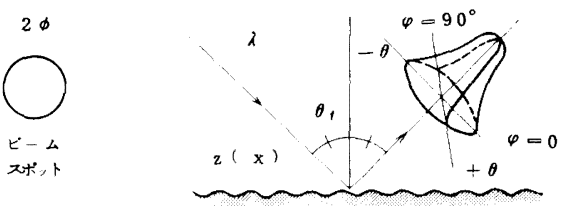

$(\sigma, \mathrm{T})$

粗度解析システム
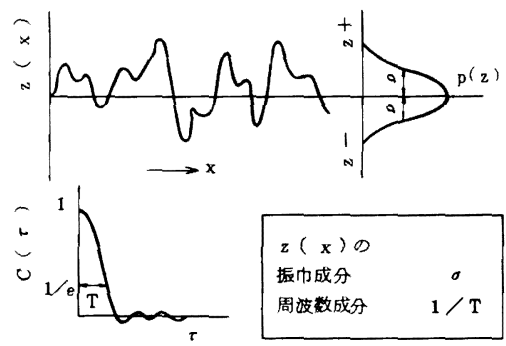

$z(x) の$ 振巾成分 周波数成分 $1 / \mathrm{T}$

半値巾による粗度測定のおっょその精度は, 実験結果から次の通りである。

測定精度 $\sim \pm 10 \%$

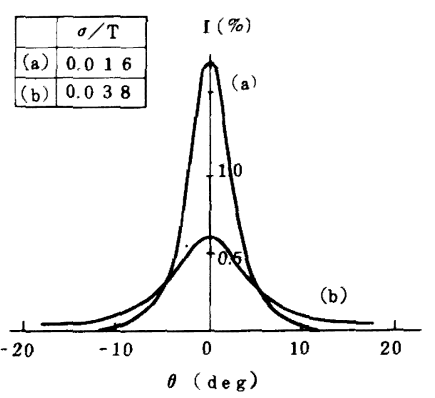

図 2 反射分布 側定例

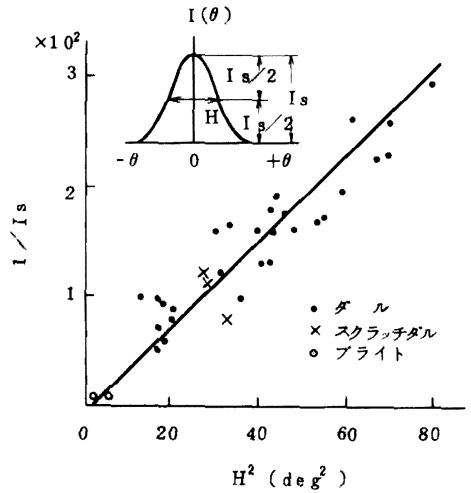

図 3 ピーク値と半值巾の関係

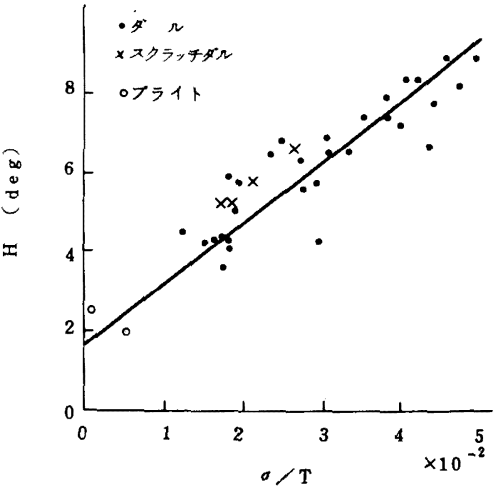

図 4 半值巾と $\sigma / \mathrm{T}$ 関保 


\section{（341） 表面粗度解析システムと鋼板粗度の解析}

新日本製鉄基礎研究所门高藤英生, 石田次雄,

草鹿履一郎

\section{1. 概 要}

従来，粗度に関しては，簡単な測定と単純な表示法による評価が行なわれていたが，鋼板表面の様な 不規則面の粗さを表現するには必ずしも適当ではなく，大量のデータの採取と，多種類の表示法を準備 しておくことが必要である。

このととは，電算機を活用するととによって初めて可能 となり, 本報告は, 市販の触針式粗度計と電算機を直結し た粗度解析システムと, それによる各種表示法の検討結果 の紹介である。

\section{2 粗度解析システム 図 1}

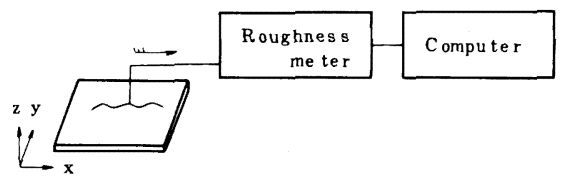

本システム㤌, L A ( Laboratory Automation)の 一環として組み込んだのである。

サンブルの表面形状 $\mathrm{z}=\mathrm{z}(\mathrm{x})$ 在自動的に測定し, 各種 解析を行なって結果を表示する。

\section{3. 鋼板粗面の解析}

銅板面につレて凹凸の高さ, 山数, 傾斜角に関する各種 表示法の検討を行なった。以下結果の一例を示す。

1) $\mathrm{Ra}$ と RMSの関倸図 2

ダル面においては， RMS=1.24 Raである。

2) PPIとPPI* の差圈 3

純粋に山数を評価するには, 現行のPPIK代えてPPI*で表示す るのが適当である。

3) $\mathrm{PPI}^{*}$ と $1 / \mathrm{T}$ の関係図 4

$\mathrm{T}$ : 自己相関の及ふ币

4) $\sigma / \mathrm{T}$ との関係図 5

$\sigma$ : 高さの確蜜密度分布の標準偏差

$\lambda$ : 急㛖度 $\lambda=\frac{1}{2 \mathrm{~L}} \int_{0}^{\mathrm{L}}\left|\frac{\mathrm{d} z}{\mathrm{dx}}\right| \mathrm{dx}$
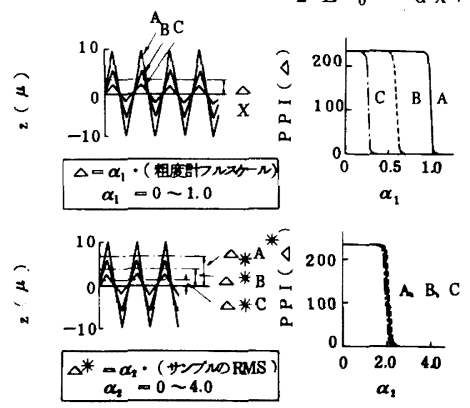

図 3 PPI とPPI*の差
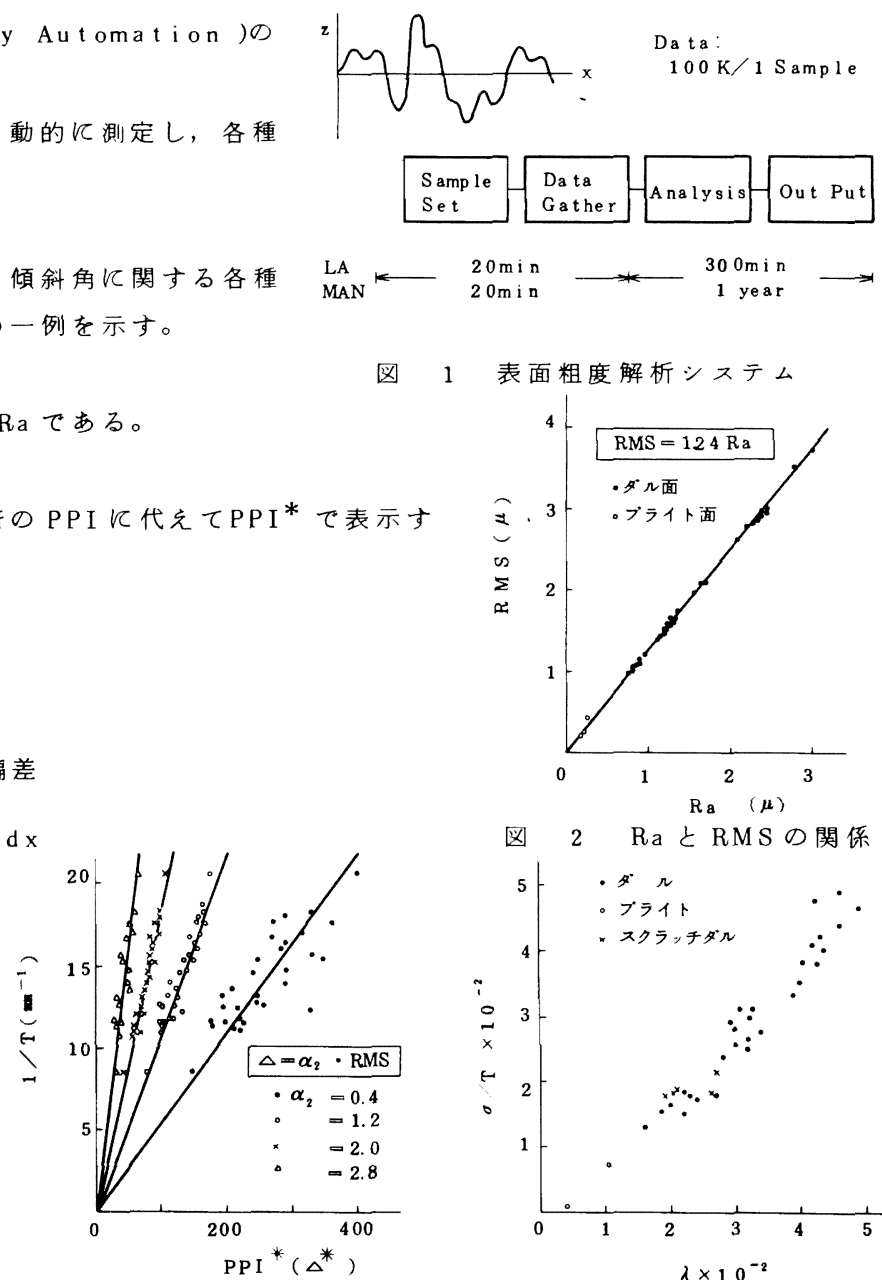

$300 \mathrm{~min}$ MAN $20 \mathrm{~min}$

図 1 表面粗度解析システム

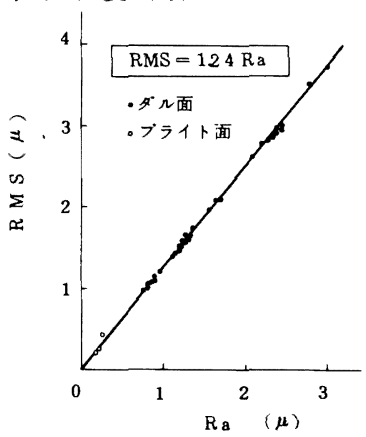

図 $2 \mathrm{Ra}$ と RMS 関係

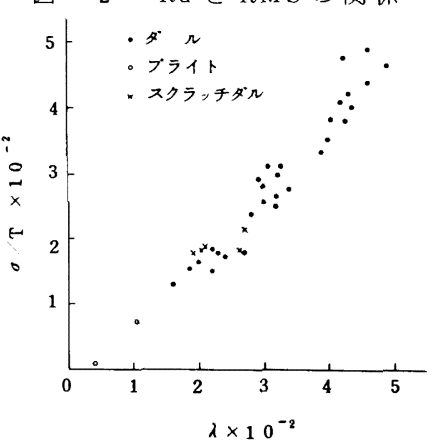

図 $4 \mathrm{PPI}^{*}$ と1 1 / $\mathrm{T}$ の関倸図 $5 \sigma / \mathrm{T}$ との関係 
'74-S 680

(342)

669.184.236: 536.5

理想的古色度湿度を持つ放射体

( 色温度と真温度の阅係- VII)

中部工業大学藤田清比古 ○山口隆生

オ八人才大学大学院伊滕昌広

色温度は分布温度七色度温度に大别できる。のうち前者は比较的解析ガ客易であるが，媵者は肉眼

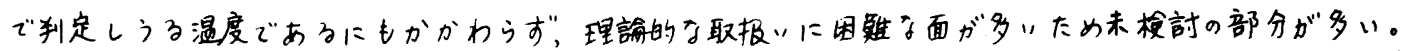
色度温度は，湿度を知了うとするする放射体からの光に等しいか，または近似的下等しい色度を持っ完

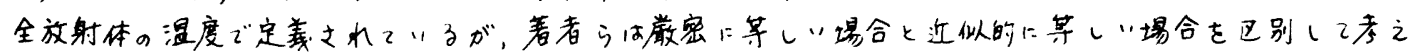

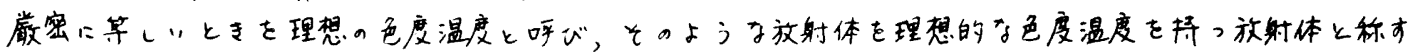
ることを提案した。今回は理想的を色度温度を持っ放射体の特性を，实在に近、条件を想定して，分光

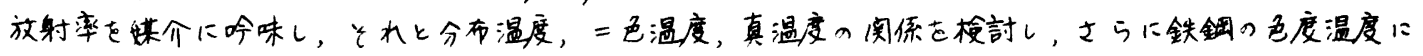
ついても考察しにので報告方る。

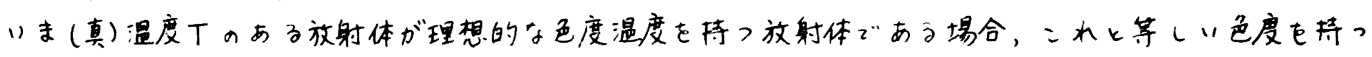

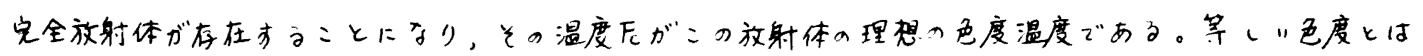

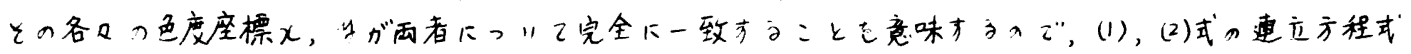
ガ成立方。

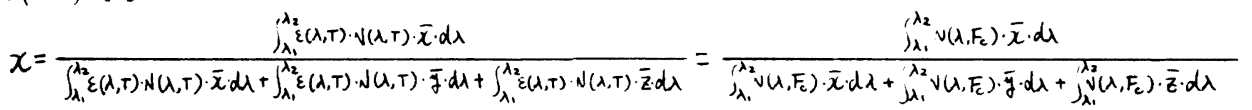

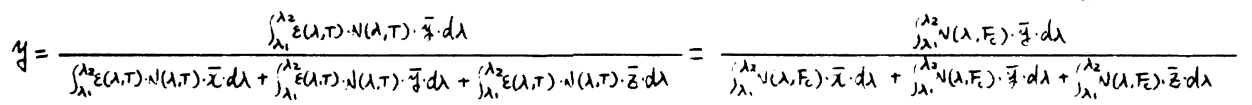

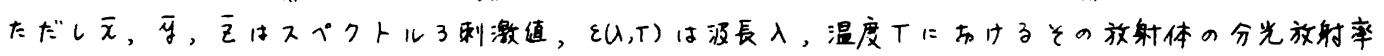

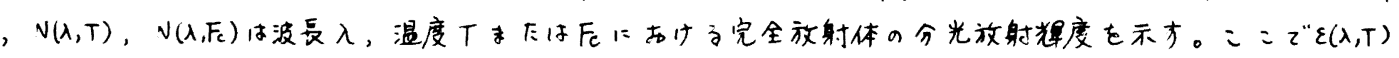

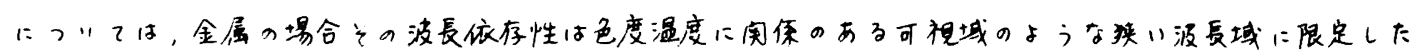

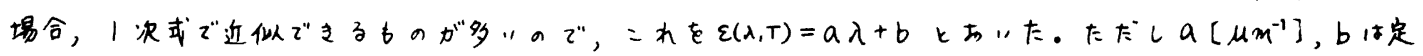

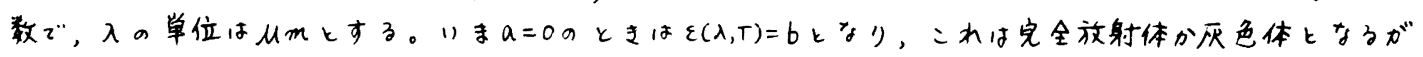

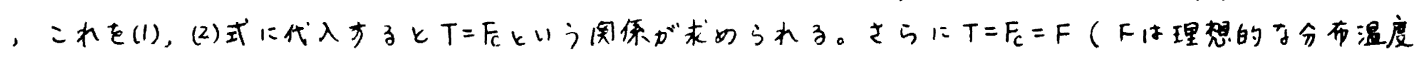

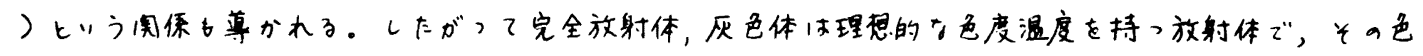

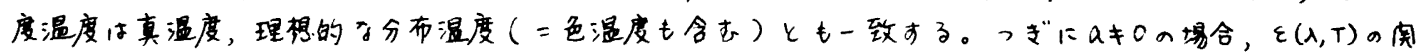

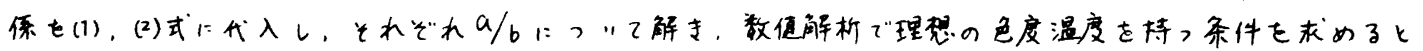

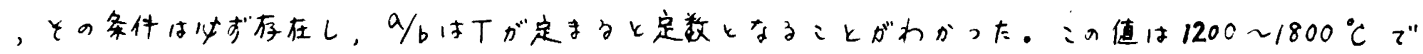

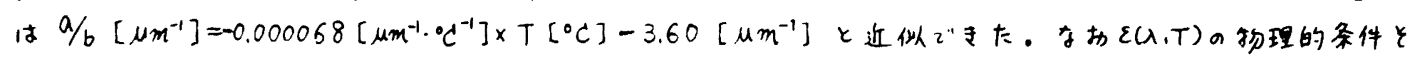

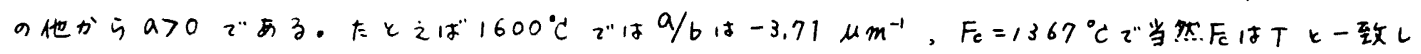

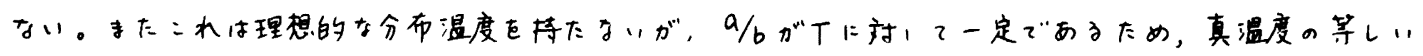
理想的子色度温度を持つ放射体の二色温度は测定服長士之同じであれば常に一定であり，二色温度の特 長の一つ七考之られる。また:れも2種颣の市販の二色湿度計で测定すると二色温度はいずれも后には

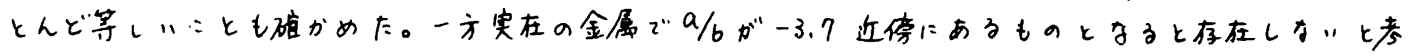
えられるが，、>0であることから酸化物なビではこの条件を渪足する可能性七予想される。つぎに

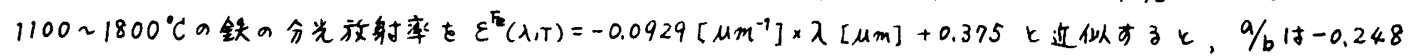

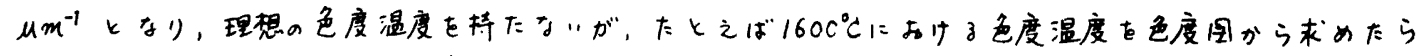

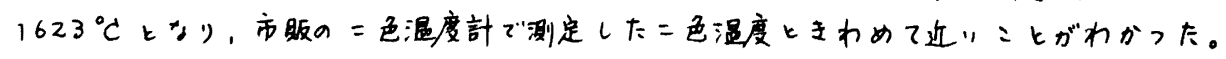




\section{(343)}

$535.331: 536.42: 669.184 .236: 543.424$

$74-S 681$

金属の分光放射率の波長依存性の测定方法

\section{中部工丵大学藤田清比古山口隆生 松下電器産業(株) ○中津川建雄}

敦言高温にあウる金属の分光放射率は，タンブステンなど特别な金属を除いては，ほとんど光高

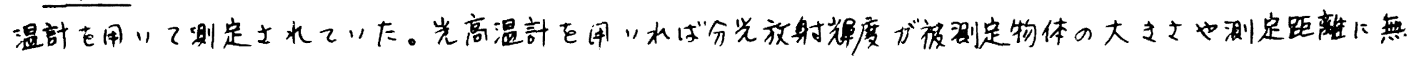
阅保に测定でまるとりう利点はらるが、一方分光特性が肉眼の视感度飞組合わされているため，測定可

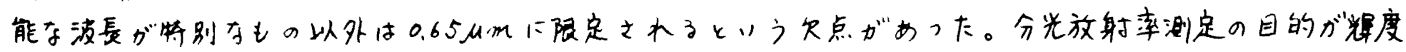
温度から真温度を知るのであればこれで十分であるが，色温度から真温度を求める埸合はもう少し広”

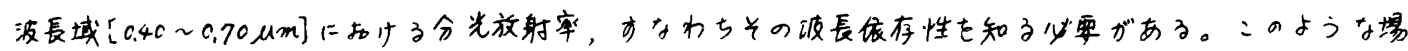
合发光部下光電子增倍管さどの物理眼を用いると，二れの出力は入射放射束に比例するため被测定物体

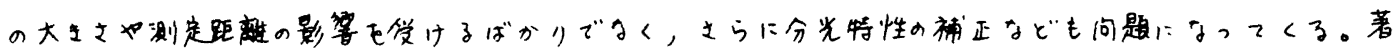

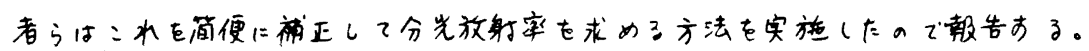

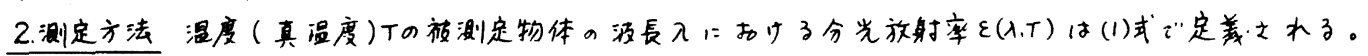

$$
W^{\prime}(\lambda, T) / \pi(\lambda, T)=\varepsilon(\lambda, T)
$$

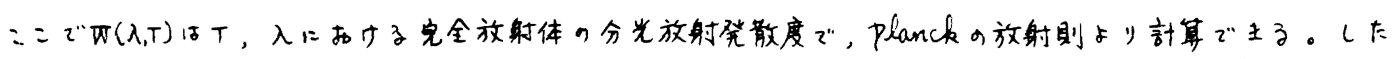

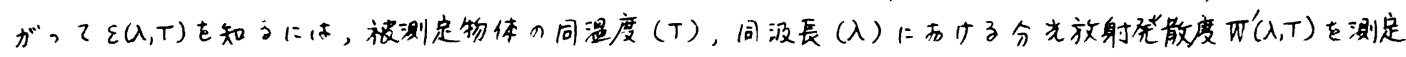

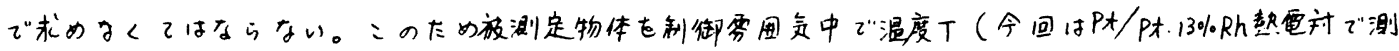

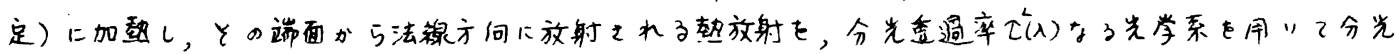

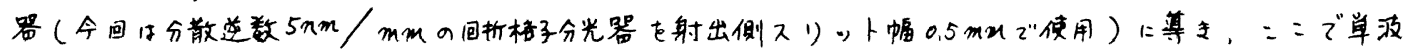

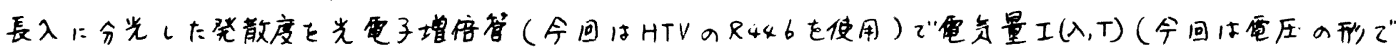

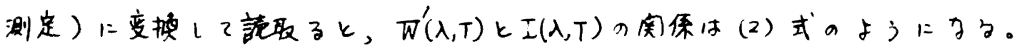

$$
I(\lambda, T)=\alpha \cdot \beta \cdot P(\lambda) \cdot \tau^{M}(\lambda) \cdot \tau^{2}(\lambda) \cdot A \cdot W^{\prime}(\lambda, T)
$$

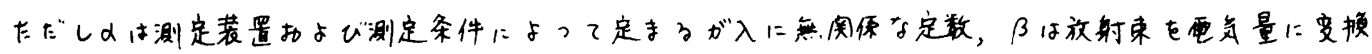

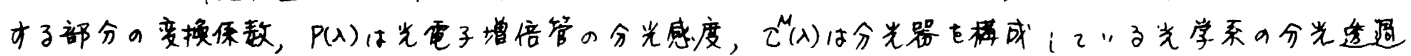
率，A山被测定物体のう弓光龟子增倍管に入射する放射を出している部分の面皘であり，二れうはいす”

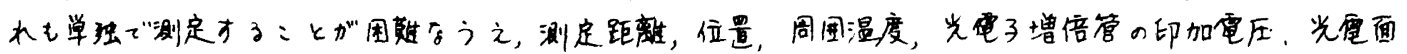

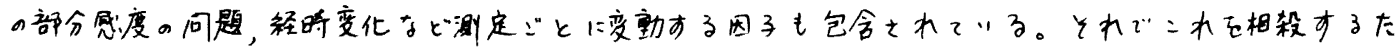

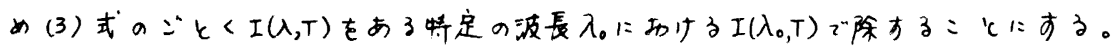

$$
I(\lambda, T) / I\left(\lambda_{0}, T\right)=\left[\left\{P(\lambda) \cdot \tau^{M}(\lambda)\right\} /\left\{P\left(\lambda_{0}\right) \cdot \tau^{M}\left(\lambda_{0}\right)\right\}\right] \cdot\left[\tau^{2}(\lambda) / \tau^{M}\left(\lambda_{0}\right)\right] \cdot\left[\pi^{\prime}(\lambda, T) / \pi^{\prime}\left(\lambda_{0}, T\right)\right]
$$

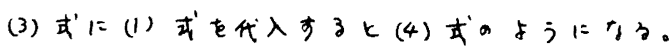

$$
I(\lambda, T) / I\left(\lambda_{0}, T\right)=\left[\left\{p(\lambda) \cdot \tau^{M}(\lambda)\right\} /\left\{p\left(\lambda_{0}\right) \cdot \tau^{M}\left(\lambda_{0}\right)\right\}\right] \cdot\left[\tau^{2}(\lambda) / \tau^{M\left(\lambda_{0}\right)}\right] \cdot\left[\varepsilon(\lambda, T) / \varepsilon\left(\lambda_{0}, T\right)\right] \cdot\left[W(\lambda, T) / W\left(\lambda_{0}, T\right)\right]
$$

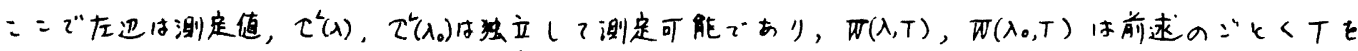

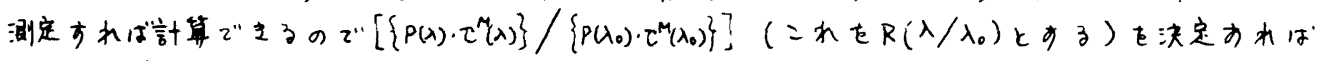

$\varepsilon(\lambda, T) / \varepsilon\left(\lambda_{0}, T\right)$ ガ求まる。したがつてある任意の入にあける分光放射率(今回は光高温部で求めた

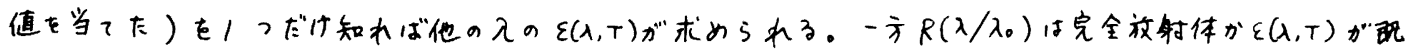

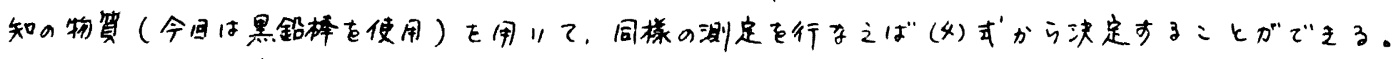

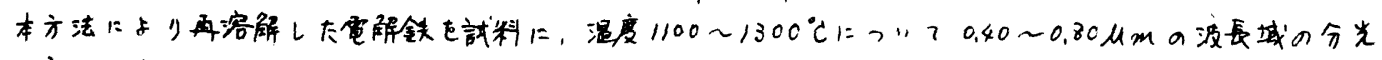

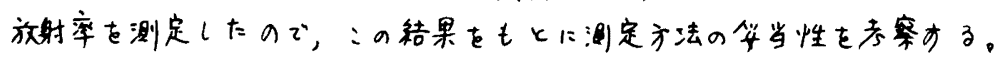


'74-S 682

(344)

621.771.016.2: 621.771.08: 536.521: 535.331

\section{鋼材酸化物の放射率}

新日本製鉄基礎研究所 $\bigcirc$ 大野二郎, 井内徹,

草鹿履一郎

1. 鋼材の可視域における放射率

熱延，厚板ラインなどでの王延時の鋼材温度管理は放射温度計が用いられている。乙の際に，基準計 器としてカッブ型表面温度計を用らている。しかし，カッブ型表面温度計は鋼材に接触させる必要加あ り, 測定が難しく精度より測定か困難である。一方，乙れまで光高温計（測定波長 0.65 〔 計器として用いられる例も多くあったが, 今回光高温計の測定波長域付近で, 中温域での鋼材放射率を 測定した結果，放射率は1.0亿近く，また安定しているととを見出した。図1に、可視域になける銅材

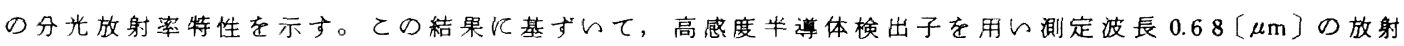

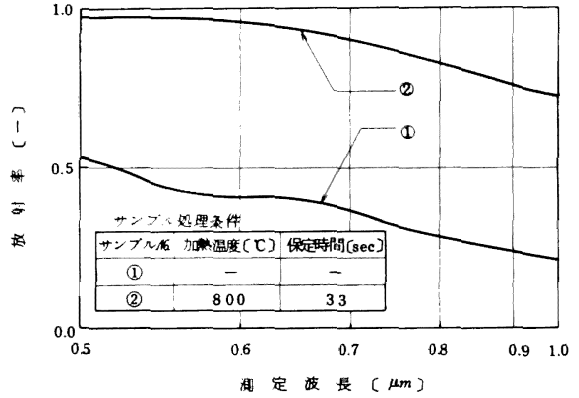

図 1. 可視域における鋼材の分光放射率

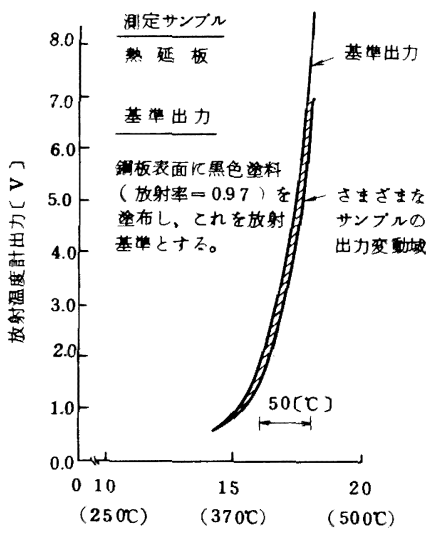

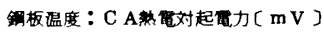
（温度換算值）

図2. 可視域温度計の出力特性

\section{3. 鋼材酸化物放射率の性質} 温度計を試作しさまさむな表面状態を有する鎘材の放 射率を測定した。この波長域で中温域の鋼材は高い放 射率を示している。従って可視域温度計は鋼材測温に おいて有力な基準計器になりらると思われる。

2 可視域温度計の測定例

実験室におらて鋼材の放射エネルギーを測定した結 果を図2に示してある。鋼材の放射率は10[\%]温度 換算で1〔\%)以内の変動巾で黒体と見なし5るととが わかる。試作計器の検出子飞はBe11\& Howe11509 光ダイオードを用いている。

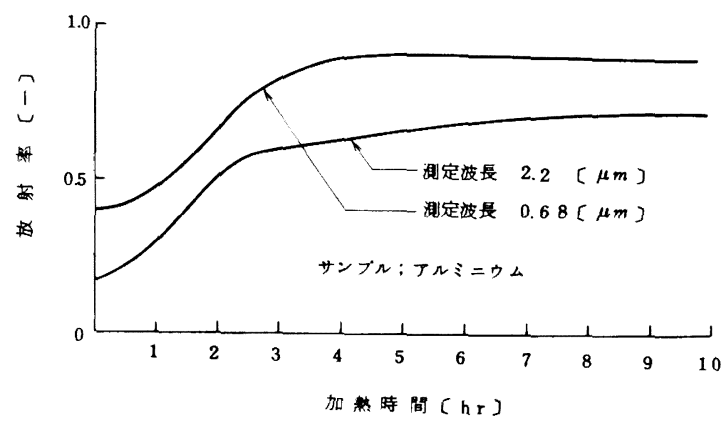

図3. A l 酸化膜厚と放射率の関係

金属酸化物の放射率を支配する因子として次の 3 点がある。

(i)酸化物の光学定数（特に消衰係数），(ii)酸化物内の散乱係数（酸化物組成の不均一なとにる） (iii)金属基盤表面の粗度

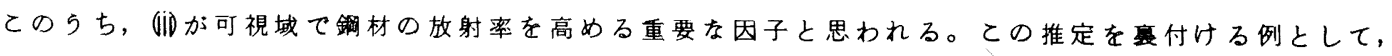
$\mathrm{A} \ell$ 板は(i)，(ii)の影䇾は少ないと考えられるが酸化膜が形成されると放射率かかなり高くなるととが認 められた。加熱倨間（酸化膜厚変化）と放射率の関係を図 3 と示す。 


\subsection{4-122.2-415: 621.785.3: 536.5 \\ (345) 冷延鋼板の常温付近の放射測温法の開発}

新日本製鉄基礎研究所 $\bigcirc$ 井内徹, 大野二郎,

草鹿履一郎

1. 緒言製品の品質維持やブロセスの解析のために常温よりわずかに高い鋼板の測温が重要になっ てきている。本報告は冷延鋼板の連続焼鈍炬出口での鋼板表面温度非接触測定を目的として開発した放 射測温法であり, この適確な測温にょり防錆のため露点以上飞保ち, 季節や乾湿の程度に応して適切な 鋼板温度に制御するととがでるる。

2 問題点と解決への方針測定対象が冷延鋼板の場合次飞列記する大をな問題点を有している。

(1) 常温付近 $\left(30 \sim 80^{\circ} \mathrm{C}\right)$ であるため周囲からの放射エネルギー，すなわち背光雑音の影響が著しい。

(2)極めて低い放射率 $\varepsilon$ のため, 放射エネルギーの検出感度がない。図3 (1)参照。

(3)放射温度計の選択飞制約がある。ボロメ一夕等の赤外長波長域 の放射検出子しか使用でをな。

一方，鋼板の表面物性を利用して問題点の解决への方針とした。

(i)連続焼鈍後の冷延鋼板清净で放射率は安定し，鏡面的反射特 性を有している。したがって，鋼板面の法線に対して角度的の 位置飞検出子を設置し, 特定の方向からしか背光雑音が入射し ないよらにするてとがでる。

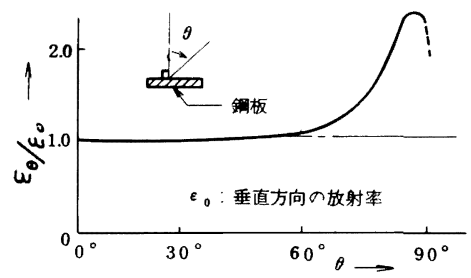

(ii)放射率 $\varepsilon$ の方向依存性を利用する。すなわち前述の $\theta_{1}$ が $80^{\circ}$ を

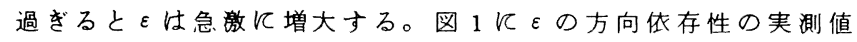
を示す。

以上の鎘板特性を利用し, 我々は1例として図2 亿示す支持口一 几を利用した放射測温法を開発した。現有設備のロール又は計測用 に新設したロールを用い, ロールと鋼板とで構成されるくさび状間 ての放射エネルギーの多重反射に上る鋼板放射率のみかけ上の増大 と， $\theta_{1}$ を $80^{\circ}$ 以上にとるととにょるとの增大およびてれらの構成に 上る背光雑音の除去, さらにロールに上る鋼板振動防止作用で計装 上の安定さなど，相乗的な測温上のメリットがある。

3. 実験結果本測定方法による効果の実験結果を述へる。 図3において, (1)は通常の測温法, 寸なわち検出子をほら゙ $\theta_{1}=0^{\circ} の$ 方向に設置して測定した場合の検出子出力て明らかに 感度は極めて恶く, (4)の黒体出力との比較から $\varepsilon=0.055$ であっ た。(2)沬(ii)の特性, すなわち $\theta_{1}=83^{\circ}$ Kした場合の検出子出力。 (3)開発した本测定方法に上る出力で十分な検出感度を有する ことがわかる。測定の結果, みかけの放射率は $\varepsilon_{a}=0.40$ であっ た。なお，使用する支持ロールとしては鋼板の レをを有する光沢性のあるロールを必要とする。周囲温度や,

図 1. 冷延鋼板放射率の方向依存性

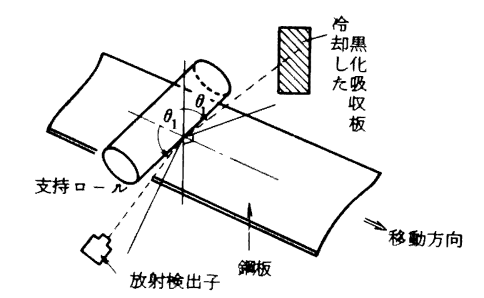

図2. 支持口ー几を利用した放射測温法

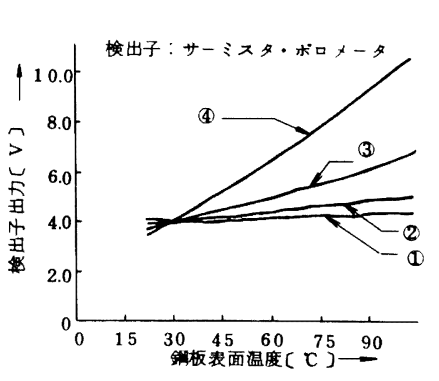

困 3. 実験データ ロール温度の変動等の外乱飞対しての影掣す検討し, 十分な $\mathrm{S} / \mathrm{N}$ 有するととが明らかとなった。 4 結言本方法は連続狫鈍炉出口ての測温以外に冷延タンデム通過後の測温等にも適する。 考文献: 温度計測粪習会テキスト 昭和 48 年 12 月 6 日 $22 / 23$ 計測自動制御学会 